\title{
RANCANG BANGUN SISTEM PENDETEKSI KEBAKARAN BERBASIS IOT DAN SMS GATEWAY MENGGUNAKAN ARDUINO
}

\author{
Dani Sasmoko \\ Program Studi Manajemen Informatika \\ Sekolah Tinggi Elektronika dan Komputer \\ Email: dani@stekom.ac.id \\ Arie Mahendra \\ Program Studi Sistem Komputer \\ Sekolah Tinggi Elektronika dan Komputer \\ Email : arie.mahendra24@gmail.com
}

\begin{abstract}
ABSTRAK
Keadaan alam di daerah PTPN IX memang berada di dataran tinggi sehingga memiliki kontur permukaan tanah yang berbukit beberapa kali terjadi kebakaran hutan yang tidak dapat di tanggulangi karena kurang nya informasi oleh karena itu di perlukan sistem yang mampu mengirim data yang di peroleh sensor dari jarak jauh.Metode pengiriman data dilakukan menggunakan metode Internet Of Things (IoT).Dengan memakai Arduino yang terhubung sensor suhu, asap ,api dan temperature yang di koneksikan dengan internet melualui SIM 900.Pengiriman data melalui IoT ini mempercepat pengiriman data kebakaran sehingga informasi kebakaran dapat di ketahui lebih cepat. Sistem lama membutuhkan waktu hingga \pm 30 menit untuk melakukan penanganan kebakaran, sedangkan pada sistem baru yang penulis lakukan hanya membutuhkan waktu beberapa menit ( $\leq 5$ menit) untuk menginformasikan ke pihak-pihak terkait dan keadaan hutan dapat terpantau setiap waktu karena menggunakan sistem realtime.
\end{abstract}

Kata kunci: arduino, IoT, kebakaran hutan, SIM 900, web, ESP 8266.

\section{ABSTRACT}

Natural conditions in the area of PTPN IX is located in the highlands so it has a hilly surface contours of land several times a forest fire that can not be overcome because of the lack of information, therefore in need of a system capable of sending data obtained by the sensor from a distance. The method of data transmission is done using the method of Internet Of Things (IoT). By using Arduino which connected temperature sensor, smoke, fire and temperature are connected to the internet through SIM 900. Data transmission through IoT speed up the transmission of fire data so that fire information can be in the know faster. The old system takes up to \pm 30 minutes to handle fire, whereas in the new system the author only takes a few minutes ( $\leq 5$ minutes) to inform the relevant parties and the forest condition can be monitored at any time as it uses real-time system.

Keywords: arduino, IoT, forest fires, SIM 900, web, ESP 8266.

\section{PENDAHULUAN}

Saat ini telah banyak terjadi peristiwa kebakaran,pada tahun 2015 lalu, Indonesia mengalami bencana kebakaran hutan yang besar di Sumatera dan Kalimantan yang mengakibatkan ribuan orang mengalami gangguan pernafasan dan mengganggu pendidikan dan roda perekonomian di daerah tersebut. Selain itu akibat dari kebakaran hutan tersebut asap yang ditimbulkan hingga mencapai ke luar negeri.

Berdasarkan statistik dari PT Perkebunan Nusantara IX dari tahun 2011 hingga sekarang setidaknya sudah terjadi sekitar 15 kali kebakaran di area hutan tersebut. Kebakaran terbesar dalam kurun waktu 5 tahun terakhir terjadi pada tahun 2015 yang mengakibatkan sekitar 1,5 hektare area hutan karet rusak dan mengalami kerugian yang cukup besar dari segi finansial. Dengan luas area 2.477,390 Ha tidak setiap saat petugas dapat mengawasi semua area hutan tersebut, jadi jika terjadi kebakaran maka tidak akan ada yang mengetahui keadaan tersebut dengan cepat. Oleh karena itu area hutan tersebut membutuhkan suatu sistem yang dapat menginformasikan kebakaran hutan secara dini yang dapat dipantau dari kantor pengawas untuk mengurangi atau menanggulangi agar kebakaran itu tidak semakin membesar dan dapat 
ditangani secara cepat. Berikut merupakan data kebakaran di PTP Nusantara IX Sukomangli dari tahun 2011-2015 :

Tabel 1. Data kebakaran pada PTP nusantara IX sukomangli

\begin{tabular}{cccc}
\hline No & Tahun & Jumlah Kebakaran & Jumlah Area Yang Terbakar \\
\hline 1 & 2011 & $3 \mathrm{kali}$ & $\geq 200$ meter 2 \\
2 & 2012 & $2 \mathrm{kali}$ & \pm 100 meter 2 \\
3 & 2013 & $2 \mathrm{kali}$ & \pm 150 meter 2 \\
4 & 2014 & $3 \mathrm{kali}$ & \pm 250 meter 2 \\
5 & 2015 & $5 \mathrm{kali}$ & $\geq 1,5$ hektare \\
\multicolumn{2}{c}{$\boldsymbol{J} \boldsymbol{M} \boldsymbol{A} \boldsymbol{A H}$} & $\mathbf{1 5}$ kali & $\pm 2,2$ hektare
\end{tabular}

Penggunaan Arduino yang terhubung dengan sensor $L M 35$ dan $M Q 7$ mampu mendeteksi kebakaran hutan yang menggunakan metode IoT yaitu mengkomunikasikan Arduino dengan internet (C.P.Mulya, 2015) yang hasil data yang terbaca oleh Arduino dari sensor akan di kirim melalui SIM 900 ke server melalui internet (M.S.Zaghloul,2014) dan mengirim SMS ke pihak yang bekepentingan untuk penanggulangan.

\section{METODOLOGI PENELITIAN}

Pada penelitian ini menggunakan beberapa tahap dari metode Research and Development (R\&D). Langkah-Langkah Penggunaan Metode R\&D

a) Potensi dan Masalah,Penelitian, semua potensi akan berkembang menjadi masalah bila tidak dapat didayagunakan dan begitupun dengan masalah jika dapat didayagunakan maka dapat dijadikan potensi.

b) Pengumpulan Data,Metode pengumpulan data yang digunakan untuk memperoleh suatu informasi tentang penelitian ini di antaranya :Observasi,Interview,Studi Literatur.

c) Desain Produk,.Dalam penelitian di PTP Nusantara IX Sukomangli, untuk pembuatan web menggunakan bahasa PHP dan pemprograman arduino menggunakan Bahasa $\mathrm{C}$ dengan aplikasi sketh untuk memprogram sensor di dalam arduino.

d) Validasi Desain,Validasi desain merupakan salah satu proses pengujian yang dilakukan guna mengetahui tingkat kebenaran produk baru tersebut. Uji validasi mengahadirkan pakar atau tenaga ahli dengan penilaian menggunakan angket. Nantinya validasi desain akan mencakup tentang pertanyaan yang kaitannya dengan sistem informasi kebakaran, dan akan divalidasi oleh pakar dan user.

e) Revisi Desain,Dalam tahap ini seorang pakar melakukan uji validasi dari desain yang dihasilkan. Jika tidak sesuai dengan tujuan awal maka peneliti akan melakukan perbaikan atau merevisi sesuai yang diminta oleh pakar.

f) Uji Coba Produk, pada penelitian ini fokus pembahasan ada pada keefektifitasan alat mengenai kebakaran dan penanganannya. Apabila model evaluasi beserta instrument ternyata belum memenuhi persyaratan pengujian akan direvisi dan diuji coba lagi. Uji coba dan revisi ini dilakukan berulang-ulang sampai diperoleh prototype akhir yang memenuhi syarat.

\section{HASIL DAN PEMBAHASAN}

Penelitian ini bertujuan untuk mengurangi resiko kebakaran dan tingkat penyakit yang disebabkan oleh asap kebakaran hutan. Alat-alat yang mendukung dalam penelitian ini yaitu Arduino Uno R3, Sensor Asap MQ-7, Sensor Suhu LM35, Sensor Api, GSM/GPRS Shield SIM900. Prinsip kerja pada keadaan awal alat diaktifkan, sensor suhu akan menampilkan laporan suhu secara real-time pada komputer/laptop yang berada pada pos sebagai acuan keadaan hutan, yg pertama adalah jika suhu normal antar $<35 \mathrm{C}$ maka indikator warna hijau akan menyala, selanjutnya adalah jika sensor asap mendeteksi adanya asap maka indikator warna kuning yang akan tampil di status peringatan pada monitoring web, dan jika suhu mencapai angka $>45 \mathrm{C}$ (A.Bayo,2010) maka indikator merah akan menyala sebagai peringatan bahaya kebakaran dan ketika sensor api mendeteksi adanya nyala api maka secara otomatis GSM/GPRS Shield SIM900 akan mengirimkan pesan SMS ke semua petugas pos jaga dan perwakilan penduduk setempat. 


\subsection{Skema Rancangan Yang Akan Di Bangun}

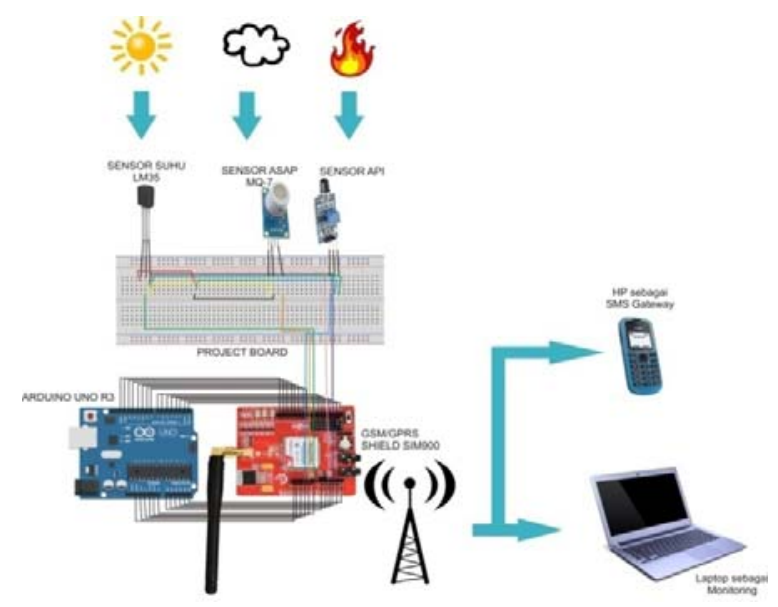

Gambar 1. Skema rancangan yang akan di bangun

Dari Skema pada gambar 1 dapat diketahui bahwa konfigurasi sistem dari sistem keamanan ini terdiri dari input, proses dan output.Dari sisi masukan (input) terdiri dari Sensor Suhu LM35, Sensor Asap $M Q-7$, dan Sensor Api. Kontroler yang digunakan adalah Arduino Uno R3 dan GSM/GPRS Shield SIM900. Sedangkan dari sisi keluaran (output) terdapat Web yang akan tanpil pada laptop dan SMS Gateway.Web yang menggunakan metode Internet Of Things ( IoT) berfungsi untuk monitoring atau sumber informasi suhu pada area hutan, sedangkan. SMS Gateway berfungsi sebagai pengirim sms secara otomatis kepetugas yang ada pada pos jaga ( T.Leriad,2015).

\subsection{Diagram Alur Kerja Arduino}

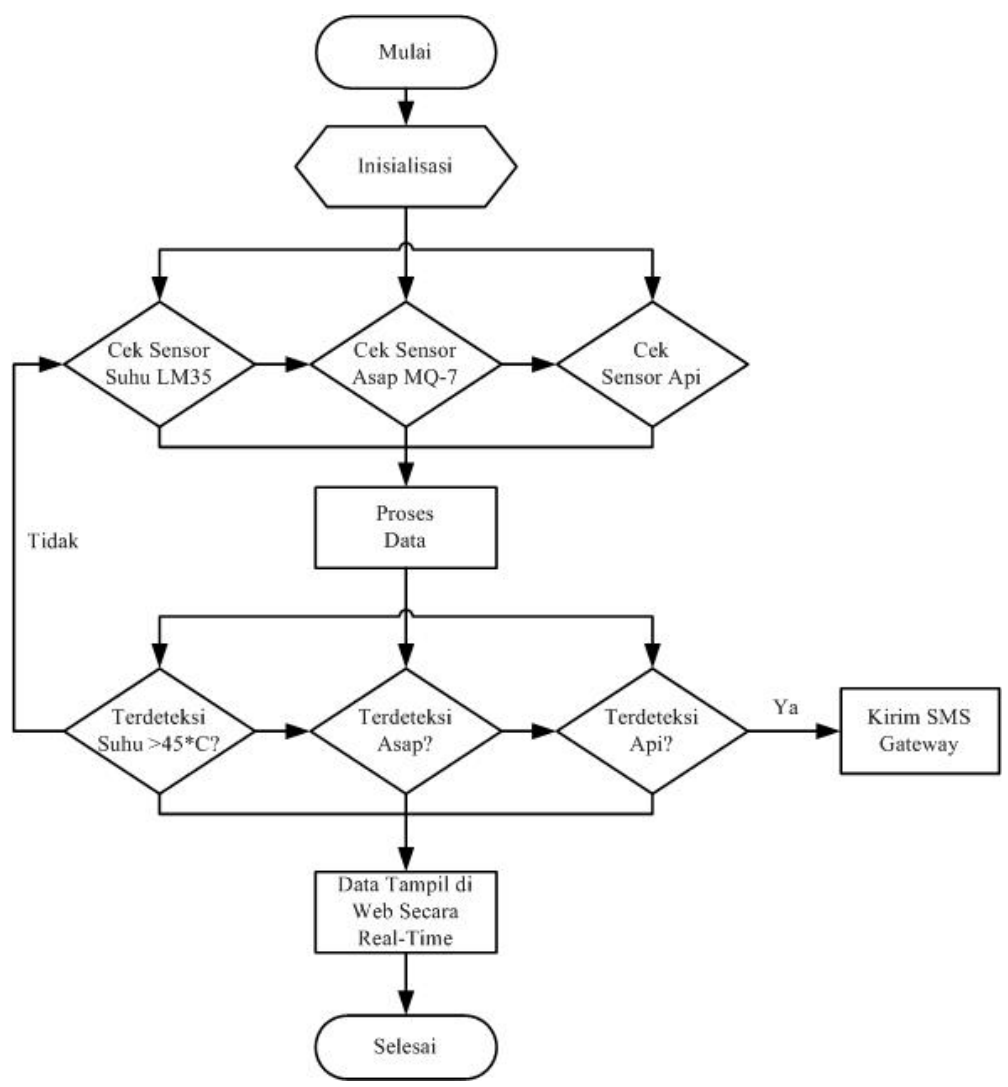

Gambar 2. Diagram Alur Kerja Arduino 
Pada gambar 2 Alur kerja arduino dapat di ketahui mulai dari inisialisasi Arduino,GSM Shield, sensor suhu, sensor asap, dan sensor api kemudian pada sistem akan mendeteksi perubahan suhu, kadar $C O$, dan api, jika kondisi melebihi batas yang di atur makan sistem akan dalam kondisi "Ya" dan mengirim SMS secara otomatis dan kemudian data akan dikirim berdasarkan hasil bacaan sensor ke database. Jika "Tidak" data hanya akan dikirim langsung ke database tanpa mengirim SMS terlebih dahulu. Data yang berada di dalam database akan di akses secara terus menerus dengan kondisi real time melalui web. Konsep monitoring hardware melalui jaringan internet ini yang biasa di sebut dengan Internet Of Things ( AK.Sharma, 2017).Proses Pengiriman data juga dilakukan melalui SMS untuk pendeteksi dini kebakaran melalui sensor $M Q-7$ yang dapat mendeteksi polutan di udara [5].

\subsection{Pengujian Sensor Api}

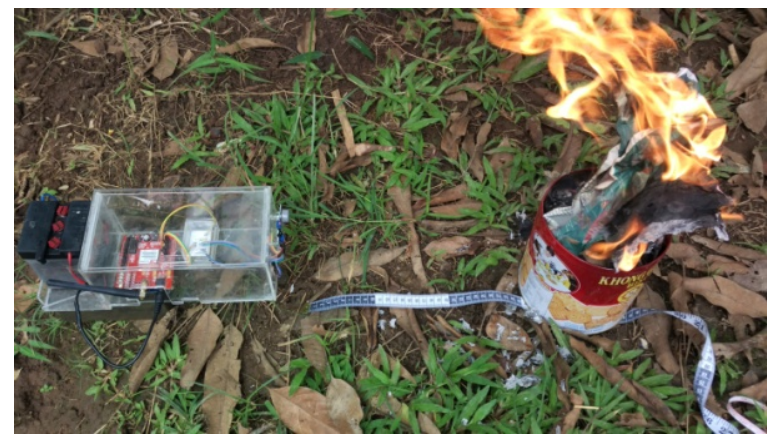

Gambar 3. Pengujian Sensor Api

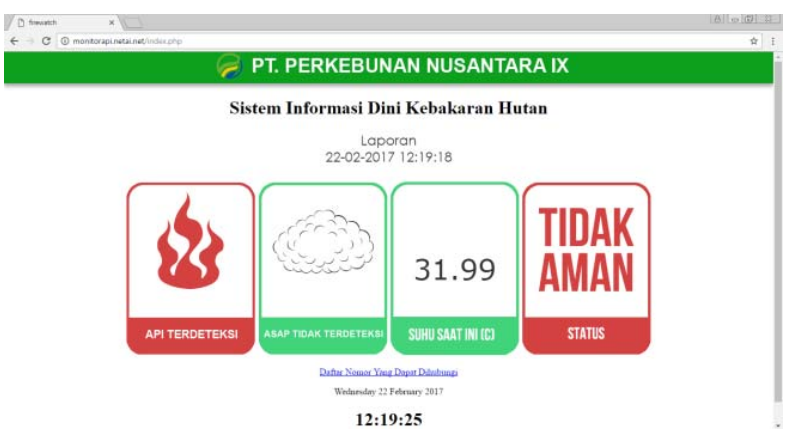

Gambar 4. Tampilan Web Pengujian Sensor Api

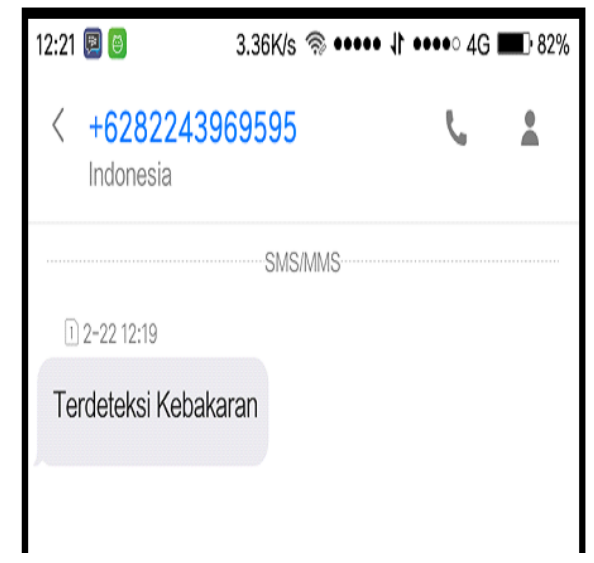

\section{Gambar 5 Tampilan SMS Pada Handphone}

Dari hasil pengujian sensor api pada gambar 3 dan pada gambar 4 hasil sensor terbaca pada web dan pada gambar 5 adalah informasi yang di peroleh dari sms, sehingga dapat disimpulkan bahwa sistem mampu meminimalisir waktu yang dibutuhkan ketika terdeteksi kebakaran. Pada uji coba tersebut jarak antara alat dengan sumber api adalah $30 \mathrm{~cm}$. Berikut merupakan waktu yang dibutuhkan sensor api. 
Tabel 2. Hasil waktu percobaan sensor api

\begin{tabular}{|c|c|}
\hline$W A K T U$ & KETERANGAN \\
\hline $00: 01$ & Sensor Api mendeteksi adanya nyala api \\
\hline 00:03 & GSM Shield mengirim SMS otomatis \\
\hline 00:03 & $\begin{array}{l}\text { Tampilan monitoring web berubah dengan } \\
\text { indikator status "TIDAK AMAN" }\end{array}$ \\
\hline
\end{tabular}

\subsection{Pengujian Sensor Asap MQ-7}

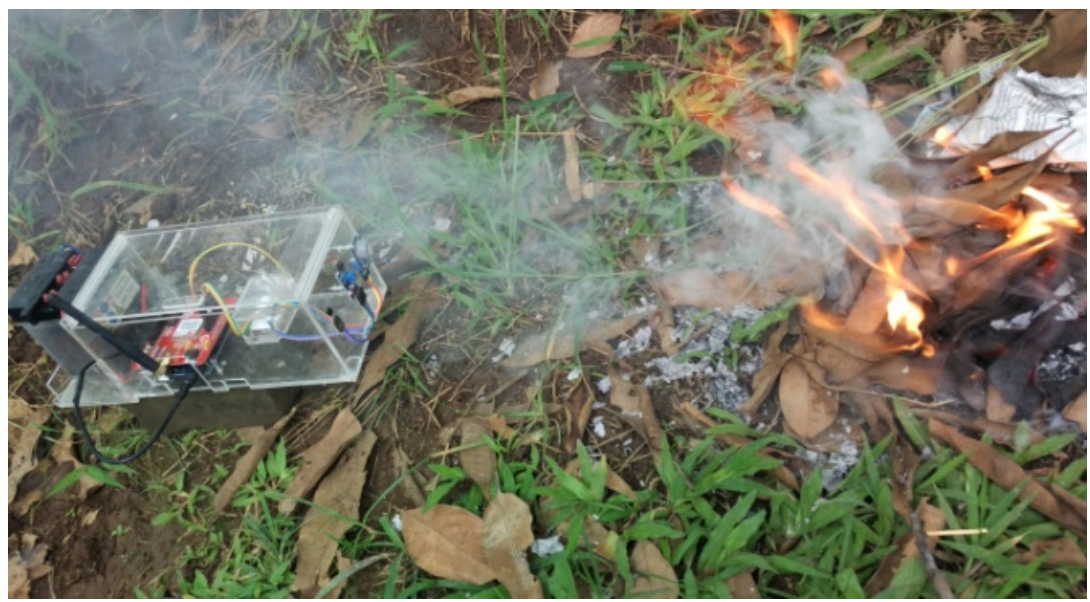

Gambar 7. Pengujian Sensor Asap $M Q-7$

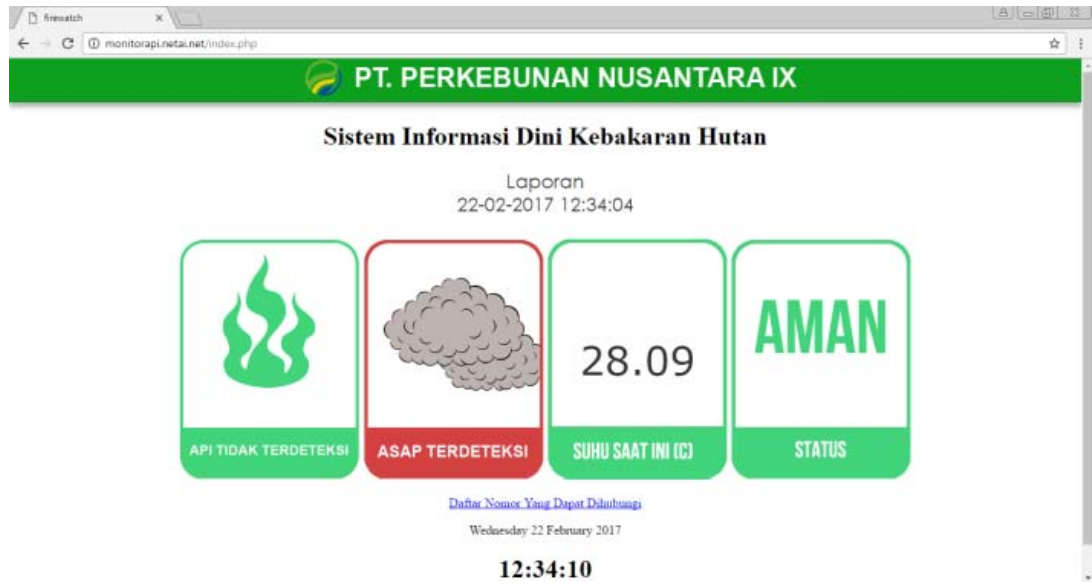

Gambar 8. Tampilan Web Pengujian Sensor Asap MQ-7

Pada gambar 7 adalah pengujian sensor asap $M Q-7$ Dari hasil pengujian sensor asap $M Q-7$ dapat disimpulkan asap akan terdeteksi hanya ketika arah angin searah dengan letak alat tersebut, ketika arah angin berbeda maka sistem tidak mampu mendeteksi meskipun ada asap. Ketika Asap terdeteksi makan di tampilkan pada web seperti yang terlihat pada gambar 8.Ada 3 ketentuan pada sensor asap $M Q-7$ :

a. Jika sensor asap mendeteksi adanya asap bersamaan dengan sensor api mendeteksi adanya nyala api maka status pada web berubah menjadi "TIDAK AMAN" dengan indikator warna merah dan secara otomatis mengirim $S M S$.

b. Jika sensor asap mendeteksi adanya asap bersamaan dengan sensor suhu dengan suhu $>45^{\circ} \mathrm{C}$ maka status pada web berubah menjadi "WASPADA" dengan indikator warna kuning dan secara otomatis mengirim SMS.

Jika hanya sensor asap mendeteksi adanya asap maka status pada web tetap pada status "AMAN" dengan indikator warna hijau. 


\subsection{Pengujian Sensor Suhu LM 35}

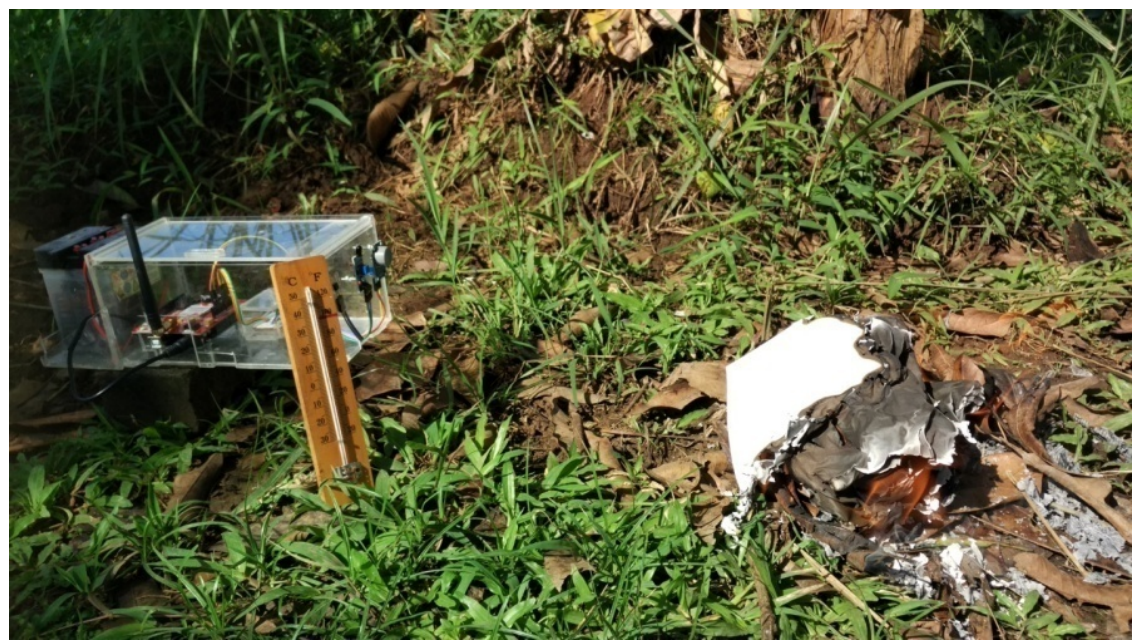

Gambar 9. Pengujian Sensor Suhu LM 35

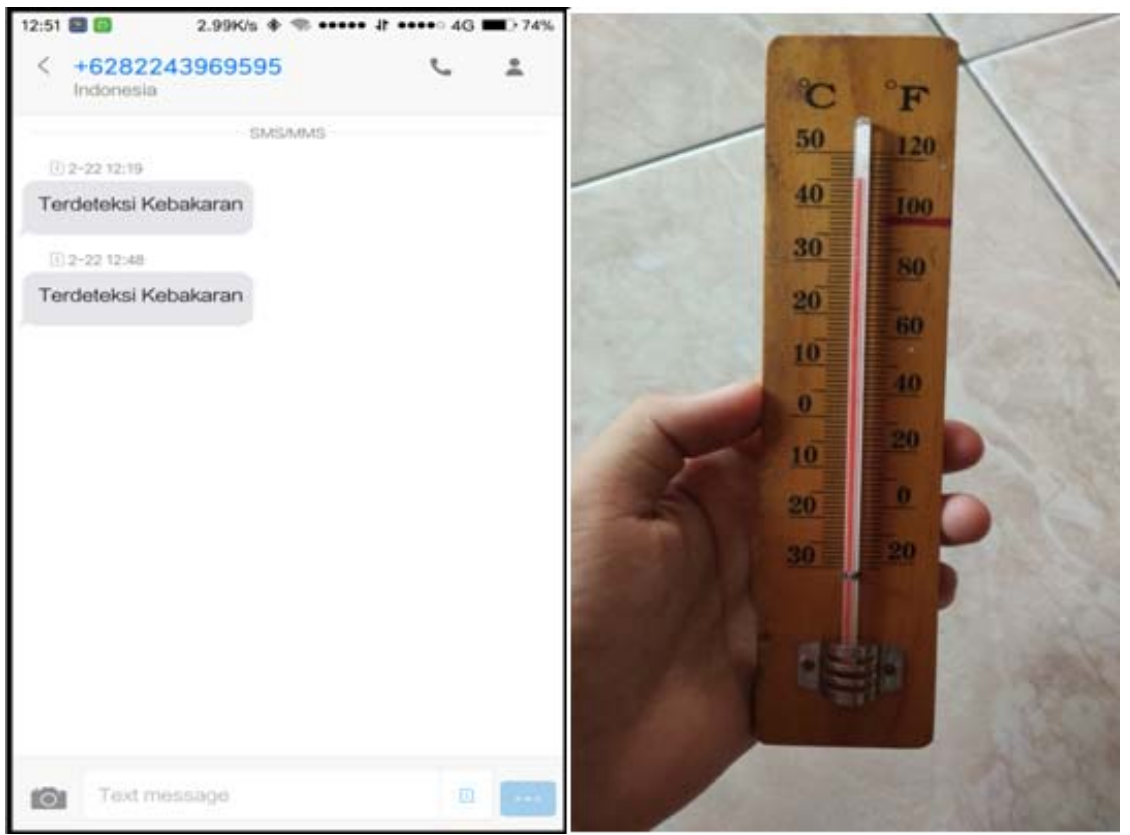

Gambar 10. Tampilan SMS Dan Hasil Temperatur

Dari hasil pengujian sensor suhu $L M 35$ pada gambar 10 dapat disimpulkan bahwa pada suhu yang dibaca dari sensor suhu $L M 35$ adalah $45.18^{\circ} \mathrm{C}$ dan suhu yang dibaca thermometer juga berada pada angka $45^{\circ} \mathrm{C}$ sehingga dapat disimpulkan bahwa sensor suhu LM35 dengan thermometer dapat membaca dan menampilkan data secara akurat, dan bersamaan dengan itu SIM900 mengirim SMS secara otomatis dan merubah tampilan web menjadi status "TIDAK AMAN" dengan indikator warna merah karena berada pada suhu $>45^{\circ} \mathrm{C}$. 


\subsection{Hasil Penelitian}

Tabel 3. Perbandingan Waktu Sistem Lama Dan Sistem Baru

\begin{tabular}{lll}
\hline Sistem & Waktu Yang Dibutuhkan & Ketika \\
& Terdeteksi Kebakaran \\
\hline Sistem Lama & \pm 30 menit & \\
Sistem Baru & $\leq 5$ menit & \\
\hline
\end{tabular}

Sistem lama membutuhkan waktu hingga \pm 30 menit untuk melakukan penanganan kebakaran, sedangkan pada sistem baru yang penulis lakukan hanya membutuhkan waktu beberapa menit ( $\leq 5$ menit) untuk menginformasikan ke pihak-pihak terkait dan keadaan hutan dapat terpantau setiap waktu karena menggunakan sistem real-time

\section{KESIMPULAN}

Rancang bangun Sistem pendeteksi kebakaran berbasis IoT dan SMS gateway ini sangat membantu memberikan informasi yang cepat untuk mengetahui kebakaran yang terjadi di hutan, dengan menggunakan metode Internet Of Things maka petugas akan mampu mengetahui kondisi secara real time, di karena kan teknologi ini mampu memonitoring hardware menggunakan sarana komunikasi internet sehingga jarak dan lokasi tidak terpengaruh asal kan sensor yang di pakai mendeteksi perubahan yang terjadi. Hasil pengujian yang telah di lakukan menghasil kan beberapa kesimpulan antara lain :

a) Sensor Api mampu mendeteksi keberadaan api akan tetapi kemampuan sensor ini kurang cukup menjangkau area yang luas, sedangkan proses transfer data keberadaan api dari sensor ke dalam database internet yang bisa di akses petugas sangat memadai di tandai waktu yang diperoleh hanya dalam hitungan detik.

b) Pada sensor asap , keberadaan asap ternyata sangat di pengaruhi oleh arah angin , jika angin berhembus ke arah sensor ketika ada asap maka sensor akan mampu mendeteksi kadar $C O$ walaupun sangat kecil perubahan nya akan tetapi bila angin bertiup ke arah sebalik nya sensor tidak akan mampu mendeteksi kadar CO.Untuk Uji sensor temperatur mampu mendeteksi suhu yang hampir mirip dengan kondisi nyata di lapangan dengan di bandingkan dengan termometer sehingga tingkat ke akuratan data sangat besar.

c) Untuk uji proses pengiriman data dari sensor melalui SIM 900 menuju database dengan menggunakan teknologi Internet Of Things tidak mengalami kendala sehingga proses pendeteksi kebakaran sangat di sarankan menggunakan metode ini.

d) Sistem lama membutuhkan waktu hingga \pm 30 menit untuk melakukan penanganan kebakaran, sedangkan pada sistem baru yang penulis lakukan hanya membutuhkan waktu beberapa menit ( $\leq 5$ menit) untuk menginformasikan ke pihak-pihak terkait dan keadaan hutan dapat terpantau setiap waktu karena menggunakan sistem real-time.

e) Penglekapan akan mati total jika terlalap api oleh karena itu peralatan ini memerlukan suatu lapisan yang anti api sehingga sensor dapat tahan api dan di saran kan tidak memakai sensor api model flame sensor 1 titik di karenakan sensor ini kurang mampu mendeteksi api dari jarak jauh sehingga tidak efektif jika ada kebakaran yang besar, selain itu sensor api 1 titik ini kurang dapat mendeteksi sinar panas matahari yang terlalu panas dan api sehingga tingkat akurasi nya sangat kurang.

\section{DAFTAR PUSTAKA}

[1] M. S. Zaghloul, "GSM-GPRS Arduino Shield (GS-001) with SIM 900 chip module in wireless data transmission system for data acquisition and control of power induction furnace," Issn 2229-5518, vol. 5, no. 4, pp. 776-780, 2014.

[2] C. P. Mulya and N. Nurkhamid, "Prototype Monitoring Kebakaran Hutan Via Website Berbasis Arduino," E-JPTE (Jurnal Elektron. Pendidik. Tek. Elektron., vol. 4, no. 7, pp. 9-18, $2015 .$.

[3] A. K. Sharma and M. A. Baig, "Iot Enabled Forest Fire Detection and Online," vol. 3, no. 5, pp. 50 54, 2017.

[4] A. Bayo, D. Antolín, N. Medrano, B. Calvo, and S. Celma, "Early detection and monitoring of forest fire with a wireless sensor network system," Procedia Eng., vol. 5, pp. 248-251, 2010.

[5] B. Tri, W. Utomo, and D. S. Saputra, "Simulasi Sistem Pendeteksi Polusi Ruangan Menggunakan Sensor Asap Dengan Pemberitahuan Melalui SMS ( Short Message Service ) Dan Alarm Berbasis 
Jurnal SIMETRIS, Vol 8 No 2 November 2017

ISSN: 2252-4983

Arduino," Ilm. Teknol. dan Informasia ASIA, vol. 10, no. 1, pp. 56-68, 2016.

[6] T. Leriad, N. Harpawi, and E. H. Putra, "Sistem Informasi Pada Fire Rescue Berbasis Wireless Sensor Network," vol. 4, no. 2, 2015. 